\title{
PENGARUH PENEMPATAN PRODUK DAN KESESUAIAN IKLAN PADA MINAT BELI YANG DIMODERASI SIKAP MEREK DI ADVERGAMES
}

\author{
Theresia Mannuela Gultom dan Albert Kriestian NAN \\ Fakultas Ekonomika dan Bisnis \\ Universitas Kristen Satya Wacana \\ Jl. Diponegoro 52-60, Salatiga 50711, Telp.0298-311881 \\ Email : 212012028@student.uksw.edu, albert.kriestian@staff.uksw.edu
}

\begin{abstract}
This study was conducted to determine the influence of Product Placement and Congruity Ads toward buying interest which is moderated by consumers' attitude on "advergames" brand. The participant of this study was 100 students of Satya Wacana Christian University, which consist of 87 male students and 13 female students. All of the participants have ever played "PES 2016" game on their mobile games application. The sampling technique was purposive sampling, with questionnaire as the data collection method. The analysis used in this study was regression analysis interaction. The result showed that there was no moderation effect of product placement and congruity ads toward purchase intention, twotypes of products in the context of the game.
\end{abstract}

Keywords: Product Placement, Ads Congruity, Purchase intention, Consumers'Attitude Abstraksi

\begin{abstract}
Abstrak: Penelitian ini dilakukan untuk mengkaji bagaimana pengaruh yang dihasilkan oleh variabel penempatan produk dan kesesuaian iklan terhadap minat beli yang di moderasi oleh variabel sikap konsumen terhadap merek di advergames. Sampel pada penelitian ini sebanyak 100 responden, 87 responden laki-laki dan 13 responden perempuan, yang merupakan mahasiswa Univeristas Kristen Satya Wacana yang pernah bermain game PES 2016 pada mobile games. Metode pengambilan data menggunakan kuesioner. Teknik pengambilan sampel adalah purposive sampling. Analisis yang digunakan adalah analisis regresi interaksi. Hasil penelitian ini menunjukkan bahwa sikap konsumen terhadap merek di advergames tidak memoderasi pengaruh penempatan produk dan kesesuaian iklan terhadap minat beli, baik pada merek atau produk yang sesuai maupun yang tidak sesuai dengan konteks game.
\end{abstract}

Kata Kunci : Penempatan Produk, Kesesuaian Iklan, Minat Beli, Sikap Konsumen terhadap Merek di Advergames

\section{PENDAHULUAN}

Suatu pasar terdiri dari begitu banyak konsumen yang beragam, seperti perbedaan bagaimana konsumen menggunakan produk dalam memenuhi kebutuhan, keinginan dan pola konsumsinya (kampus.marketing. co.id). Menyikapi hal tersebut pemasar harus mampu menciptakan komunikasi pemasaran yang efektif (Kotler dan Armstrong, 2008) untuk memahami kebutuhan serta perilaku konsumen. Qolbi, dkk (2014) mendefinisikan pemasaran sebagai proses merancang dan mengkomunikasikan strategi yang mempengaruhi persepsi konsumen terhadap produk yang ditawarkan oleh suatu perusahaan. Strategi kreatif harus dirancang agar perusahaan mampu bersaing dalam mengenalkan merek atau produk terhadap konsumen sasarannya. Salah satu komunikasi pemasaran dan strategi efektif yaitu melalui media periklanan (Kotler dan Armstrong, 2008).

Dalam hal media periklanan, perkembangan teknologi informasi menjadi berkembang pesat dan memungkinkan pemasar lebih variatif dalam memanfaatkan teknologi untuk merancang ide periklanan dengan media iklan baru seperti media iklan melalui permainan atau game (Sahni, 2009). Jenis media periklanan seperti ini sering disebut dengan advergames, atau 
iklan dalam permainan (Qolbi, dkk., 2014). Advergames merupakan media iklan yang berkembang sangat pesat di Indonesia, ini bukti bahwa game diakui berperan sebagai media penyampai informasi (tekno.kompas. com). Keunggulan iklan melalui media game yaitu memberi kebebasan lebih kepada konsumen karena mereka melakukan tanpa adanya paksaaan (Ajisaksono dan Wiratmojo, 2014). Berbeda dengan iklan televisi (lean back entertainment), ketika melihat iklan di televisi penonton bisa saja melakukan atau memikirkan hal lain, sedangkan berbeda dengan seseorang yang bermain game mereka akan memfokuskan $100 \%$ perhatiannya pada game yang dimainkan. Hal tersebut memungkinkan daya ingat konsumen terhadap merek atau produk melalui media iklan dalam game akan lebih besar (Ajisaksono dan Wiratmojo, 2014).

Menurut Peters and Leshner (2013), advergames merupakan video game dimana sebuah merek atau produk secara teknis masuk ke dalam sebuah game. Advergames yang memasukkan sebuah merek atau produk sering dikenal sebagai komunikasi pemasaran melalui penempatan produk (Parreno, dkk., 2013). Penempatan produk merupakan kegiatan pemasaran dalam iklan dan promosi yang memasukkan nama merek, produk, kemasan, tanda, dan ciri khas produk tersebut masuk ke dalam suatu media yang mempunyai tujuan komersil untuk menimbulkan minat beli (Panda, 2004). Salah satu tujuannya membawa keinginan akan perubahan sikap konsumen dan evaluasi secara keseluruhan terhadap merek atau produk tersebut (Pramoedya, 2013) sehingga berdampak pada perilaku pembelian (Nelson, dkk., 2004).

Selain itu penempatan produk erat kaitannya dengan kesesuaian iklan, dimana menurut Williams, dkk (2011) semakin kuat kesesuaian iklan menunjukkan bahwa merek atau produk yang ditempatkan memiliki keterkaitan yang jelas dan logis dengan jenis game, sehingga penempatan produk akan terlihat alami dan konsiten dengan game tersebut, dan sebaliknya. Hal ini sejalan dengan penelitian Nelson, dkk (2004) yang menyatakan dalam komunikasi penempatan produk, aspek kesesuaian iklan dalam game juga penting diteliti, untuk melihat apakah merek atau produk yang ditempatkan di dalam game akan mengurangi pengalaman pemain dan menganggu pemain dalam bermain game atau sebaliknya.

Qolbi, dkk (2014) dalam penelitiannya menguji mengenai penempatan produk dan kesesuaian iklan dalam game terhadap sikap konatif konsumen. Hasil dari penelitian menemukan bahwa penempatan produk dan kesesuaian iklan dalam game masing-masing dan secara bersamaan berpengaruh terhadap sikap konatif konsumen, dimana menurut Xiong, dkk (2015) sikap konatif konsumen didasarkan pada munculnya minat beli. Artinya, konsumen menjadi tertarik untuk melakukan pembelian dikarenakan adanya penempatan produk dan kesesuaian iklan yang baik dengan game yang dimainkan.

Penelitian ini memodifikasi penelitian Qolbi, dkk (2014), dimana permasalahan penelitian adalah pengaruh penempatan produk dan kesesuaian iklan pada minat beli dengan variabel sikap konsumen terhadap merek di advergames sebagai variabel yang memoderasi. Alasan modifikasi yang dilakukan menggunakan sikap konsumen terhadap merek sebagai variabel moderasi yaitu, didasarkan pada penelitian yang telah dilakukan Wise, dkk (2008) yang menemukan bahwa perubahan sikap konsumen terhadap merek disebabkan adanya kesenangan lebih besar terhadap merek atau produk yang relevan dibandingkan tidak relevan dengan game. Pada penelitian selanjutnya Parreno, dkk (2013) menemukan bahwa sikap konsumen terhadap merek di advergames dapat berbeda, dipengaruhi oleh dimensi entertainment dan dimensi irritation, dimana sikap konsumen terhadap merek di advergames akan lebih positif dikarenakan game dapat memberikan rasa senang atau hiburan saat bermain game tersebut, dan sebaliknya sikap konsumen terhadap merek di advergames akan berdampak pada sikap negatif dikarenakan konsumen menganggap bahwa iklan merek atau produk yang muncul sebagai gangguan ketika bermain. Suwito (2007) dalam studinya menemukan bahwa sikap konsumen terhadap merek berpengaruh terhadap minat beli konsumen, dimana sikap konsumen terhadap merek tersebut diawali oleh proses kognitif yang bekerja pada rangsangan, kemudian akan mempengaruhi minat beli konsumen terhadap merek atau produk yang ditawarkan. 
Berdasarkan hal tersebut, peneliti menggunakan sikap konsumen terhadap merek di advergames sebagai variabel moderasi untuk menentukan terlebih dahulu sikap yang dihasilkan konsumen terhadap merek atau produk, apakah sikap positif atau sikap negatif yang ditunjukkan, karena menurut Sutisna (2002) dalam Pujadi (2010) sikap positif terhadap merek akan memungkinkan konsumen melakukan pembelian terhadap merek, namun sebaliknya sikap negatif akan mengurangi konsumen untuk melakukan pembelian, sehingga berdasarkan hal tersebut sikap konsumen terhadap merek di advergames dimungkinkan dapat memperkuat atau memperlemah pengaruh yang dihasilkan dari penempatan produk dan kesesuaian iklan terhadap minat beli.

Perbedaan penelitian ini dari penelitian sebelumnya adalah untuk membuktikan apakah variabel sikap konsumen terhadap merek di advergames mampu memperkuat atau memperlemah pengaruh penempatan produk dan kesesuaian iklan terhadap minat beli. Selain itu perbedaan dengan penelitian sebelumnya, dalam penelitian ini menggunakan advergames yang ada pada mobile games. Mobile games digunakan karena dalam kategori penggunaan smartphone di Jepang dan Korea Selatan bermain game merupakan aktivitas terlama di urutan kedua (id.techinasia.com), bahkan di dunia yang serba mobile ini, game menjadi bagian tak terpisahkan bagi kehidupan manusia yang bisa dimainkan kapanpun dan dimanapun (www.antaranews.com). Di Indonesia, jumlah pengguna mobile mencapai 52,5 juta dari 250 juta penduduk, dimana sebagian besar peminat game mendownload game versi mobile (www. arbamedia.com).

Penelitianinibertujuanmengkajipengaruh variabel penempatan produk dan kesesuaian iklan pada minat beli yang dimoderasi sikap konsumen terhadap merek di advergames pada mobile games. Responden penelitian adalah mahasiswa dan mahasiswi Universitas Kristen Satya Wacana Salatiga yang berusia 17-24 tahun. Pembatasan usia mengacu pada kesenjangan kelompok pengguna yang paling kontributif dalam menyumbang Click Through Rates pada iklan dalam game dan paling efektif dalam berinteraksi dengan iklan online. Remaja dengan usia 14-18 tahun merupakan kategori aktif dalam berinteraksi dengan iklan online, sedangkan kelompok pengguna dalam rentang usia 2534 di Vietnam dan usia 45-54 di Indonesia masuk ke dalam kategori kelompok yang banyak menyumbang CTR pada iklan game (autotekno.sindonews.com). Berdasarkan hal tersebut, maka peneliti menggunakan rentang usia 17-24 tahun sebagai obyek yang belum diteliti untuk digunakan dalam penelitian ini, selain itu menggunakan responden mahasiswa dan mahasiswi UKSW Salatiga, mengacu pada penelitian yang dilakukan Chaney, dkk (2004) yang melakukan penelitian dengan menggunakan usia responden 16-45 tahun dan yang paling tinggi dalam berkontribusi berada di usia 16-25 tahun sebanyak 50\% dari jumlah responden yang ditetapkan merupakan pelajar, sehingga dalam penelitian ini juga menggunakan mahasiswa dan mahasiswi sebagai obyek yang diteliti.

Jenis game pada mobile games dalam penelitian ini adalah game Pro Evolution Soccer (PES) 2016 yang merupakan game olahraga sepakbola di mobile games. Diharapkan hasil penelitian ini memberi referensi bagi pemasar dalam menganalisis penempatan produk dan kesesuaian iklan untuk produk yang diiklankan terhadap minat beli, sehingga menjadi informasi pendukung dalam menyusun strategi promosi khususnya periklanan, serta memberi masukan bagi pengguna game dalam mempertimbangkan minat beli mereka terhadap setiap produk yang muncul di dalam game baik produk yang sesuai maupun yang tidak sesuai.

\section{TINJAUAN PUSTAKA}

\section{Penempatan Produk}

Williams, dkk (2011) mendefinisikan penempatan produk sebagai praktek pemasaran dalam iklan dan promosi dimana nama merek atau produk, kemasan, dimasukkan dan digunakan secara kontekstual dalam film, televisi, atau media lain untuk tujuan komersial. Winkler dan Buckner (2006) mencatat penempatan produk sebagai istilah yang digunakan untuk merujuk pada posisi dimana sebuah gambar yang menampilkan merek atau produk di dalam media hiburan, seperti pada game online. 
Russell (2002) dalam Pramoedya (2013) membedakan penempatan produk dalam 3 dimensi, yaitu :

\section{Dimensi Visual / Screen Placement.}

Dimensi visual merujuk pada tampilan dari merek dalam layar. Ada 3 faktor yang mempengaruhi, yaitu (a) ruang atau space pada layar. (b) durasi produk pada layar. (c) berapa jumlah dari total scene yang disisipi produk.

\section{Dimensi Auditory/Script Placement.}

Dimensi ini merujuk pada penyebutan secara lisan terhadap merek atau produk oleh pemain dalam program penempatan produk, misalnya nada pada suara, penempatan dalam dialog, dan cara karakter atau pemain berbicara.

\section{Dimensi Plot Connection.}

Dimensi ini merujuk pada seberapa terkaitnya antara merek dengan alur cerita. Dalam konteks ini plot connection merujuk pada alur di dalam permainan, yaitu (a) tampilan logo yang mencirikan jenis produk. (b) paparan merek atau produk. (c) hubungan merek yang diiklankan dengan game.

Dalam penelitian ini hanya akan menggunakan 2 (dua) dimensi dari penempatan produk, yaitu : dimensi visual (screen placement) dan dimensi plot connection, karena objek yang akan diteliti pada penelitian ini adalah game PES 2016, dimana dalam game tersebut tidak ada unsur dari script placement atau yang merujuk pada penyebutan secara lisan mengenai merek atau produk yang ditampilkan.

\section{Kesesuaian Iklan}

Kesesuaian adalah suatu hal yang menunjukkan hubungan antara dua objek (Sukandar, 2012). Menurut Williams, dkk (2011) kesesuaian iklan seperti yang terjadi pada advergames merupakan keterkaitan yang jelas dan logis antara kategori merek atau produk dengan konteks game. Dalam penelitian yang dlakukan Sukandar (2012) mengukur kesesuaian iklan atas website menggunakan 4 (empat) dimensi, yaitu:

\section{Dimensi Estetika}

Dimensi estetika mencakup segala hal terkait objek yang dapat dirasakan oleh panca indera. Dua aspek yang menjadi bagian dari dimensi estetika adalah stylishness dan design. Stylishness menggambarkan rancangan suatu iklan. Sedangkan design lebih menggambarkan keselarasan atau harmonisasi antara iklan dengan kondisi sekitarnya.

\section{Dimensi Konteks}

Fokus perhatian dimensi ini adalah konsistensi dan relevansi informasi mengenai suatu produk yang diiklankan. Konsumen melihat bahwa informasi yang ditampilkan suatu iklan akurat dan relevan dengan konteks, maka ia akan mempersepsikan iklan tersebut sesuai.

\section{Dimensi Relevansi}

Dalam hal ini, pada penelitian ini dimensi relebansi digunakan untuk mengukur kesesuaian bentuk iklan dengan game sebagai tempat iklan.

\section{Dimensi Ekspektasi}

Pada dimensi ekspektasi, yang menjadi fokus adalah pada simbol atau gambar dari tampilan suatu iklan.

\section{Sikap Konsumen terhadap Merek di Advergames}

Penelitian Parreno, dkk (2013) mencatat sikap terhadap merek dalam advergames menggunakan dimensi entertainment dan irritation, dimana keduanya sebagai kunci mengevaluasi sikap konsumen terhadap merek diadvergames.Entertainmentdiidentifikasikan sebagai sikap positif konsumen terhadap advergames karena mampu menimbulkan respon positif seperti senang atau terhibur, sedangkan irritation merupakan alasan utama mengapa kebanyakan orang merasa bosan dan tidak menyukai iklan, karena menganggap iklan yang muncul menggangu ketika bermain game. Ketidaknyamanan atas iklan menjadi penyebab munculnya persepsi negatif atas suatu iklan dalam game yang dapat mengarah pada pembentukan sikap yang negatif.

\section{Minat Beli}

Minat beli diperoleh dari suatu proses belajar dan proses pemikiran yang membentuk suatu persepsi. Minat beli ini menciptakan suatu motivasi yang terus terekam dalam benaknya dan menjadi suatu keinginan sangat kuat, yang pada akhirnya ketika konsumen harus memenuhi kebutuhannya akan mengaktualisasikan apa yang ada didalam benaknya (Pujadi, 2010). Minat beli 
memiliki indikator pengukuran dikatakan oleh Schiffman dan Kanuk (2008) : 1) Ingin mengetahui produk, 2) tertarik untuk mencari informasi mengenai produk, 3) tertarik untuk mencoba, 4) mempertimbangkan untuk membeli, 5) ingin membeli produk.

\section{Pengaruh Penempatan Produk pada Minat Beli}

Penempatan produk di media hiburan sudah menjadi suatu hal yang umum, dilihat berdasarkan bagaimana konsumen memproses pesan iklan yang disampaikan dari sebuah merek atau produk yang muncul dalam suatu media hiburan tersebut (Lee dan Faber, 2007). Beberapa penelitian terdahulu telah dilakukan mengenai penempatan produk dalam konteks online games (Lee dan Faber, 2007), video music (Nurpratama, 2014) dan television (Zulganef dan Ramadhika, 2014).

Penelitian Lee dan Faber (2007) menyatakan penempatan produk berpengaruh terhadap sikap positif konsumen dalam konteks online games. Hal tersebut dikarenakan penempatan produk yang dilihat dari lokasi merek dalam game, keterlibatan konsumen dalam game dan pengalaman konsumen dalam game sebelumnya mampu mempengaruhi memori konsumen tentang suatu merek atau produk yang diiklankan dalam game. Chen dan Haley (2014) mendukung dengan hasil penelitian yang menemukan bahwa keterlibatan konsumen dalam game akan meningkatkan minat beli konsumen terhadap merek atau produk. Hal ini menunjukkan bahwa keterlibatan konsumen dengan penempatan produk sebagai faktor yang menyebabkan meningkatnya minat beli konsumen terhadap merek atau produk yang diiklankan.

Pada penelitian yang dilakukan oleh Nurpratama (2014) menemukan pengaruh dari penempatan produk terhadap minat beli konsumen. Hal tersebut dikarenakan penempatan produk yang ada pada video music menampilkan keaslian dari produk dan mereknya di dalam video tersebut, sehingga menjadi preferensi atau kesukaan peminat musik terhadap suatu media.

Noguti dan Rusell (2014) dalam Zulganef dan Rahmadika (2014) menyatakan bahwa product placement effect dalam bentuk presumed influence, merupakan efek tidak langsung yang terdiri dari dua model tahapan : (1) seseorang melihat pengaruh pesan pada orang lain, dan (2) kemudian bereaksi berdasarkan persepsi terhadap pengaruh tersebut dengan mengubah perilaku mereka sendiri, yang akhirnya mempunyai pengaruh terhadap minat beli merek yang ditempatkan dalam film serial di TV. Sama halnya dengan penelitian yang dilakukan oleh Qolbi, dkk (2014) yang menemukan bahwa terdapat pengaruh penempatan produk terhadap sikap konatif konsumen dimana menurut Xiong, dkk (2015) sikap konatif ditunjukkan dengan minat beli.

Namun, berbeda dengan hasil penelitian yang dilakukan Zulganef dan Rahmadika (2014) yang menyatakan bahwa penempatan produk di suatu program televisi tidak berpengaruh pada minat beli konsumen. Hal tersebut dikarenakan konsumen cenderung menganggap bahwa merek yang muncul di suatu program tersebut tidak dikenal, sehingga tidak memunculkan minat beli konsumen terhadap merek tersebut. Berdasarkan perbedaan pada penelitian terdahulu, maka hipotesis pertama pada penelitian ini untuk verifikasi terhadap perbedaan tersebut, dan dinyatakan sebagai berikut :

\section{H1: Penempatan produk berpengaruh terhadap minat beli}

\section{Pengaruh Kesesuaian Iklan pada Minat Beli}

Kesesuaian erat kaitannya dengan persepsi seorang individu. Adanya perbedaan persepsi ideal dengan persepsi nyata menjadi suatu penyebab munculnya efek kesesuaian, karena secara psikologis individu akan berusaha untuk mencapai tahapan persepsi yang ideal menurutnya. Berdasarkan hal tersebut, persepsi berbeda yang diciptakan oleh individu atas suatu objek pada akhirnya akan berujung pada suatu pemicu yang akan menentukan tindakan individu tersebut (Sukandar, 2012). Tindakan yang dilakukan individu inilah yang kemudian menjadi suatu sikap atas objek, dimana persepsi seorang individu semakin mendekati kesesuaian maka kemungkinan munculnya sikap positif atas objek terkait akan semakin besar dan 
sebaliknya (Zajonck, 1980 dalam Sukandar, 2012) .

Kesesuaian iklan dalam advergames merupakan kesesuaian antara kategori produk dengan konteks game, yang akan mempengaruhi sikap konsumen melalui daya ingat konsumen yang tinggi terhadap suatu produk dibandingkan iklan yang tidak sesuai (Lee dan Faber, 2007). Hal tersebut disebabkan karena kategori produk yang sesuai dengan konteks games akan menghasilkan daya ingat konsumen lebih tinggi terhadap sebuah merek atau produk. Daya ingat konsumen tersebut dibangun berdasarkan sikap positif konsumen terhadap kesesuaian antara kategori produk dan konteks game (Gross, 2010).

Lee dan Faber (2007) menyatakan bahwa ketika sebuah pesan iklan atau informasi dari merek atau produk yang disampaikan sesuai dan saling berkaitan terhadap konteks game, maka sikap konsumen akan positif terhadap iklan dan menyebabkan meningkatnya daya ingat konsumen terhadap pesan iklan yang disampaikan didasarkan pada kesesuaiannya, dimana salah satu sikap positif konsumen tersebut akan menghasilkan minat beli konsumen terhadap suatu merek atau produk. Didukung oleh Qolbi, dkk, (2014) bahwa kesesuaian iklan antara kategori merek atau produk dengan konteks game memiliki peranan penting terhadap sikap konsumen. Hasil penelitiannya menemukan bahwa kesesuaian iklan berpengaruh terhadap minat beli konsumen.

Berdasarkan hal tersebut maka hipotesis yang dirumuskan dalam penelitian ini :

H2: Kesesuaian iklan berpengaruh terhadap minat beli

\section{Pengaruh Penempatan Produk pada Minat Beli dengan Sikap Konsumen terhadap Merek di Advergames sebagai Variabel Moderasi}

Nelson (2002) dalam Sharma, dkk (2007) menyatakan bahwa sikap konsumen terhadap praktek penempatan produk di dalam game menunjukkan sikap positif karena tidak menganggap bahwa penempatan produk merupakan sebuah gangguan dalam pengalaman bermain konsumen. Sikap positif konsumen tersebut menunjukkan emosi atau perasaan suka konsumen dengan kemunculan penempatan produk yang tepat di dalam game. Namun, sebaliknya konsumen cenderung akan bersikap negatif dan menolak ketika penempatan produk tidak tepat (Nelson, dkk., 2004).

Penelitian yang dilakukan oleh Chaney, dkk., (2004) menemukan tingkat recall dari suatu merek rendah untuk penempatan produk di dalam video games. Hal tersebut dikarenakan pengalaman pemain terhadap suatu game tidak dapat menjelaskan kemampuan pemain dalam mengingat suatu merek atau produk seperti pada tampilan billboard dalam video games, dikarenakan seorang pemain yang memiliki pengalaman pada suatu game akan cenderung fokus pada game tanpa memperhatikan billboard yang muncul. Namun, masuknya penempatan produk dalam bentuk billboard ke dalam suatu game dapat mendorong minat beli konsumen.

Menurut Tsai, dkk (2007) dalam Williams, dkk (2011) minat beli tersebut dipengaruhi oleh kesadaran konsumen terhadap merek atau produk yang ditempatkan di dalam sebuah game. Dimana semakin tinggi kesadaran terhadap suatu merek atau produk maka sikap terhadap penempatan produk positif dan pengaruhnya pada tingkat recall dan minat beli semakin tinggi.

Berdasarkan hal tersebut peneliti menduga untuk memperkuat atau memperlemah pengaruh penempatan produk terhadap minat beli, peneliti menggunakan sikap konsumen terhadap merek di advergames sebagai variabel moderasi. Sehingga hipotesis yang dirumuskan dalam penelitian ini yaitu :

\section{H3: Sikap terhadap merek di advergames memoderasi pengaruh penempatan produk terhadap minat beli \\ Pengaruh Kesesuaian Iklan pada Minat Beli dengan Sikap Konsumen terhadap Merek di Advergames sebagai Variabel Moderasi}

Moore, dkk., (2005) dalam studinya menemukan pengguna internet memiliki perbedaan dalam hal memproses informasi yang terkandung dalam suatu pesan. Tampilan iklan pada website yang memiliki tingkatan kesesuaian rendah akan menarik lebih 
banyak perhatian, namun tak sampai pada pembentukan sikap. Sedangkan tampilan iklan yang memiliki tingkatan kesesuaian tinggi akan lebih mudah untuk mengarahkan pembentukan sikap ke arah yang lebih positif.

Pada lingkup advergames, Qolbi, dkk., (2014) menemukan bahwa kesesuaian iklan berpengaruh positif terhadap sikap konsumen, khususnya pada sikap konatifkonsumen. Sikap konatif konsumen didasarkan pada munculnya minat beli, (Xiong, dkk, 2015) menyatakan bahwa sebelum melakukan pembelian sebuah merek atau produk, konsumen membangun sikap positif terlebih dahulu terhadap merek atau produk tersebut. Sikap positif konsumen itu dipengaruhi oleh adanya kesesuaian iklan dari merek atau produk dengan game yang dimainkan. Setelah terbentuk sikap positif konsumen terhadap merek atau produk maka selanjutnya konsumen akan mengevaluasi merek atau produk tersebut secara positif berdasarkan kesesuaian iklan dengan konteks game (Peters dan Leshner, 2013). Penelitian yang dilakukan oleh Suwito (2007) dan Pujadi (2010) mencatat terdapat pengaruh sikap terhadap merek terhadap minat beli konsumen.

Berdasarkan hal tersebut peneliti menduga terdapat pengaruh dari kesesuaian iklan terhadap minat beli yang dimoderasi oleh sikap konsumen terhadap merek di advergames, sehingga hipotesis yang dirumuskan dalam penelitian ini yaitu :

H4: Sikap terhadap merek di advergames memoderasi pengaruh kesesuaian iklan terhadap minat beli

\section{MODEL PENELITIAN}

Berdasarkan hipotesis dan hubungan antar variabel yang telah diuraikan di atas dapat digambarkan kerangka konseptual penelitian ini sebagai berikut:

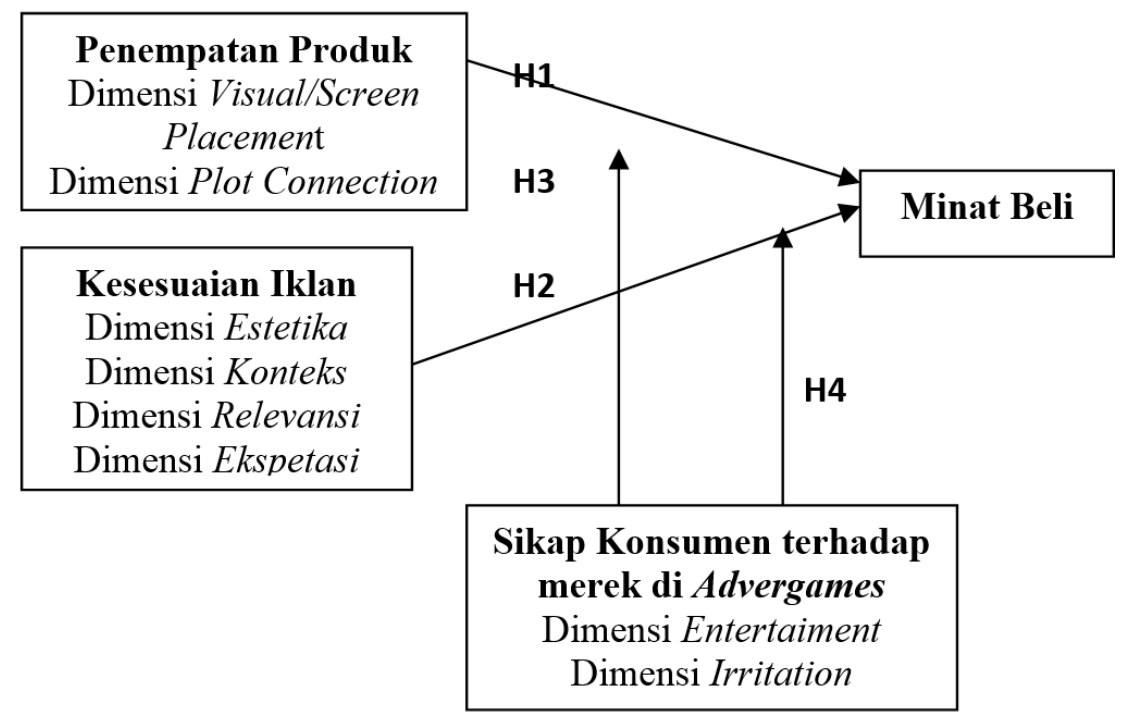

Gambar 1 : Model Penelitian

Sumber: Konsep yang dikembangkan dalam penelitian

\section{METODOLOGI PENELITIAN}

Populasi penelitian ini adalah mahasiswa Universitas Kristen Satya Wacana Salatiga. Teknik pengambilan sample yang digunakan adalah purposive sampling, yaitu teknik penentuan sampel dengan pertimbangan tertentu, yaitu mempertimbangkan responden yang berusia 17-24, dan yang pernah bermain game PES 2016 pada mobile games. Dari 110 kuesioner yang telah disebar sebanyak 103 kuesioner yang kembali dan 100 kuesioner yang dapat diolah, 3 kuesioner tidak dapat diolah karena tidak layak, terutama informasi yang diberikan responden tidak lengkap, sehingga hanya 100 data yang dianalisis. Pada penelitian ini teknik analisis yang dipakai adalah regresi interaksi dengan salah satu variabel sebagai variabel moderasi. 


\section{HASIL PENELITIAN DAN PEMBAHASAN}

Tabel 1. Karakteristik Responden

\begin{tabular}{|c|c|c|c|c|}
\hline No & Kategori & Sub Kategori & Frekuensi & Presentase \\
\hline \multirow{8}{*}{1.} & \multirow{8}{*}{ Usia } & 17 & 2 & $2 \%$ \\
\hline & & 18 & 5 & $5 \%$ \\
\hline & & 19 & 11 & $11 \%$ \\
\hline & & 20 & 16 & $16 \%$ \\
\hline & & 21 & 29 & $29 \%$ \\
\hline & & 22 & 20 & $20 \%$ \\
\hline & & 23 & 10 & $10 \%$ \\
\hline & & 24 & 7 & $7 \%$ \\
\hline \multirow{2}{*}{2.} & \multirow{2}{*}{ Jenis Kelamin } & Laki-laki & 87 & $87 \%$ \\
\hline & & Wanita & 13 & $13 \%$ \\
\hline \multirow{3}{*}{3.} & \multirow{3}{*}{ Usia mulai bermain games } & 3-8 tahun & 50 & $50 \%$ \\
\hline & & 9-13 tahun & 34 & $34 \%$ \\
\hline & & 14-18 tahun & 16 & $16 \%$ \\
\hline \multirow{3}{*}{4.} & \multirow{3}{*}{$\begin{array}{l}\text { Usia mulai bermain mobile } \\
\text { games }\end{array}$} & 6-11 tahun & 27 & $27 \%$ \\
\hline & & 12-17 tahun & 55 & $55 \%$ \\
\hline & & 18-22 tahun & 18 & $18 \%$ \\
\hline
\end{tabular}

Sumber : Data primer diolah, 2016

Di dalam penelitian ini terdapat berbagai karakteristik responden untuk mendukung analisis penelitian ini, yaitu ditunjukkan pada Tabel 2. Tabel 2 pada karakteristik responden menunjukkan berdasarkan usia, responden mayoritas berusia 21 tahun yaitu sebanyak 29 orang dengan persentase $29 \%$ dengan jumlah responden paling banyak berjenis kelamin laki-laki yaitu 87 orang dengan persentase $87 \%$. Berdasarkan usia mulai bermain games, mayoritas responden berusia dalam rentang 3-8 tahun sebanyak 50 orang dengan persentase $50 \%$. Mayoritas usia responden mulai bermain mobile games yaitu sebanyak 55 orang dengan persentase $55 \%$ di rentang usia 12-17 tahun.

Pengalaman responden bermain game PES 2016 pada mobile games dilihat berdasarkan alasan responden menggunakan mobile games, berapa bulan responden telah memainkan game PES 2016 pada mobile

games, waktu yang dihabiskan bermain game PES 2016 pada mobile games dalam seminggu, dan waktu yang dihabiskan setiap kali bermain game PES 2016 pada mobile games. Tabel 3 menunjukkan bahwa mayoritas responden menggunakan mobile games dengan alasan praktis, yaitu sebanyak 51 orang dengan persentase 51\%. Sebagian besar responden telah memainkan game PES 2016 selama 1-2 bulan sebanyak 41 orang dengan persentase sebanyak 41\%. Sedangkan untuk waktu yang sudah dihabiskan responden dalam bermain game PES 2016 pada mobile games menunjukkan bahwa mayoritas responden menghabiskan antara 2-3 kali dalam seminggu sebanyak 35 orang dengan persentase $35 \%$ dan menghabiskan 2-3 jam setiap kali bermain sebanyak 47 orang dengan persentase $47 \%$. Secara keseluruhan Tabel 3 menunjukkan beragam kebiasaan dan pengalaman responden terhadap game PES 2016 pada mobile games. 
Tabel 2. Pengalaman Mobile Games

\begin{tabular}{|c|c|c|c|c|}
\hline No & Kategori & Sub Kategori & Frekuensi & Presentase \\
\hline \multirow{3}{*}{1.} & \multirow{3}{*}{$\begin{array}{l}\text { Alasan menggunakan mobile } \\
\text { games }\end{array}$} & Mudah digunakan & 26 & $26 \%$ \\
\hline & & Lebih banyak pilihan & 23 & $23 \%$ \\
\hline & & Praktis & 51 & $51 \%$ \\
\hline \multirow{3}{*}{2.} & \multirow{3}{*}{$\begin{array}{l}\text { Sudah berapa lama bermain } \\
\text { game PES } 2016 \text { pada mobile } \\
\text { games }\end{array}$} & $1-2$ bulan & 41 & $41 \%$ \\
\hline & & 3-4 bulan & 35 & $35 \%$ \\
\hline & & $5-6$ bulan & 24 & $24 \%$ \\
\hline \multirow{3}{*}{3.} & \multirow{3}{*}{$\begin{array}{l}\text { Rata-rata bermain PES } 2016 \\
\text { pada mobile games dalam } \\
\text { seminggu }\end{array}$} & 1 kali dalam seminggu & 34 & $34 \%$ \\
\hline & & 2-3 kali dalam seminggu & 35 & $35 \%$ \\
\hline & & $>3$ kali dalam seminggu & 31 & $31 \%$ \\
\hline \multirow{3}{*}{4.} & \multirow{3}{*}{$\begin{array}{l}\text { Rata-rata waktu yang } \\
\text { dihabiskan dalam sehari } \\
\text { bermain PES } 2016 \text { pada mobile } \\
\text { games }\end{array}$} & 1 jam & 37 & $37 \%$ \\
\hline & & Jam & 47 & $47 \%$ \\
\hline & & $>3$ jam & 16 & $16 \%$ \\
\hline
\end{tabular}

Sumber : Data primer diolah, 2016

\section{Uji Validitas dan Reliabilitas}

Total sebanyak 100 responden, dengan nilai $r$ tabel adalah 0,195 dan alfa 5\%. Dari hasil olah data menunjukan bahwa pada setiap butir pertanyaan dari variabel penempatan produk, kesesuaian iklan, sikap konsumen terhadap merek di advergames dan minat beli valid, karena memiliki nilai $>0,195$ ( $\mathrm{r}$ tabel). Dari uji reliabilitas, keempat variabel mempunyai nilai Cronbach's Alpha $>0,6$. Variabel penempatan produk Adidas mempunyai nilai Cronbach's Alpha sebesar 0,653. Variabel kesesuaian iklan Adidas mempunyai Cronbach's Alpha sebesar 0,834 . Variabel sikap konsumen terhadap merek Adidas mempunyai Cronbach's Alpha sebesar 0,649 Variabel minat beli Adidas mempunyai Cronbach's Alpha sebesar 0,901 . Variabel penempatan produk Nissan mempunyai nilai Cronbach's Alpha sebesar 0,750. Variabel kesesuaian iklan Nissan mempunyai Cronbach's Alpha sebesar 0,713. Variabel sikap konsumen terhadap merek Nissan mempunyai Cronbach's Alpha sebesar 0,762 . Variabel minat beli Nissan mempunyai Cronbach's Alpha sebesar 0,763. Semua nilai Cronbach's Alpha lebih besar dari 0,6, oleh karena itu dapat disimpulkan bahwa semua variabel adalah reliabel. Berdasarkan hasil tersebut dapat dikatakan bahwa semua butir soal adalah valid dan reliabel.

\section{Uji Asumsi Klasik}

Setelah diketahui bahwa data dinyatakan valid dan reliabel, peneliti melakukan uji asumsi klasik sebelum melakukan uji regresi interaksi. Didalam uji asumsi klasik terdapat uji normalitas, uji linearitas, dan uji multikolinieritas. Variabel yang digunakan telah lulus uji asumsi klasik. 


\section{Hasil dan Analisis}

Tabel 3. Pengaruh Penempatan Produk dan Kesesuaian Iklan Terhadap Minat Beli yang di Moderasi oleh Sikap Konsumen terhadap Merek Adidas di Advergames

\begin{tabular}{|c|c|c|c|c|c|}
\hline \multicolumn{6}{|c|}{ Coefficients } \\
\hline \multirow[t]{2}{*}{ Model } & \multicolumn{2}{|c|}{$\begin{array}{l}\text { Unstandardized } \\
\text { Coefficients }\end{array}$} & \multirow{2}{*}{$\begin{array}{c}\text { Standardized } \\
\text { Coefficients }\end{array}$} & \multirow[t]{2}{*}{$\mathbf{t}$} & \multirow[t]{2}{*}{ Sig } \\
\hline & B & Std. Error & & & \\
\hline (constant) & -4.912 & 3.534 & & -1.390 & .168 \\
\hline Penempatan Produk Adidas & .300 & .143 & .180 & 2.102 & .038 \\
\hline Kesesuaian Iklan Adidas & .302 & .095 & .358 & 3.177 & .002 \\
\hline $\begin{array}{l}\text { Sikap Konsumen terhadap } \\
\text { Merek Adidas (SK) }\end{array}$ & .355 & .116 & .307 & 3.045 & .003 \\
\hline PPAS_X_SK Adidas & -.005 & .034 & -.012 & -.134 & .894 \\
\hline KSAS_X_SK Adidas & -.010 & .010 & -.088 & -.916 & .362 \\
\hline a. Dependent Variable: MBA & at Beli & das) & & & \\
\hline
\end{tabular}

Sumber : Data diolah,2016

Berdasarkan pengolahan data diatas, menunjukkan bahwa penempatan produk dan kesesuaian iklan mempengaruhi minat beli konsumen pada produk yang sesuai dengan konteks game, dimana jenis produk yang digunakan adalah Adidas. Hal ini ditunjukkan dengan nilai signifikan penempatan produk sebesar $(0,038)$ dan nilai signifikan kesesuaian iklan sebesar $(0,002)$ lebih kecil dari nilai signifikan $(0,05)$. Pada pengujian ini, rata-rata responden setuju terhadap setiap pertanyaan mengenai penempatan produk dan kesesuaian iklan yang mempengaruhi minat beli pada produk Adidas. Pada penelitian ini, rata-rata skor tertinggi pada aspek penempatan produk terdapat di butir 4 yang mengungkapkan bahwa minat beli konsumen lebih besar dipengaruhi oleh tampilan produk atau gambar logo yang digunakan di dalam game yang mencirikan jenis produk tersebut dengan rata-rata skor 4,09 , sedangkan rata-rata skor tertinggi sebesar 4,18 pada aspek kesesuaian iklan terdapat di butir 3 yang mencatat bahwa minat beli konsumen lebih besar dipengaruhi oleh adanya kesesuaian iklan dengan konteks game, yaitu merek Adidas sebagai jenis produk olahraga yang sesuai diiklankan pada konteks game olahraga seperti game PES 2016. Hal tersebut juga diungkapkan Williams, dkk (2011) yang mengungkapkan bahwa kesesuaian iklan yang kuat menunjukkan bahwa merek atau produk yang ditempatkan memiliki keterkaitan yang jelas dan logis dengan jenis game, sehingga penempatan produk akan terlihat alami dan konsisten dengan game tersebut. Namun ketika kesesuaian iklan lemah, penempatan produk akan terlihat tidak konsisten dan tidak kredibel dengan game tersebut. Hal ini sesuai dengan penelitian yang dilakukan oleh Qolbi, dkk (2014), yang membuktikan bahwa penempatan produk dan kesesuaian iklan dalam advergames mempengaruhi sikap konatif konsumen yang ditunjukkan dengan minat beli.

Berdasarkan pengolahan data di atas juga menunjukkan adanya pengaruh yang dihasilkan dari variabel sikap terhadap merek di advergames terhadap minat beli konsumen. Hal tersebut ditunjukkan dengan nilai signifikan 0,003 lebih kecil dari nilai signifikan 0,05 . Skor tertinggi untuk variabel sikap terhadap merek di advergames terhadap minat beli ditunjukkan pada butir 3 yang menyatakan bahwa responden mengingat merek Adidas yang muncul di dalam advergames. Hal ini menunjukkan bahwa responden cenderung tertarik membeli suatu merek atau produk karena responden mengingat merek atau produk yang muncul pada game yang dimainkan. Hal ini sejalan dengan hasil penelitian Pujadi (2010) yang menyatakan bahwa sikap terhadap merek pada indikator merek diingat merupakan indikator yang paling dominan, hal ini memberikan pemahaman bahwa dengan merek yang diingat maka dapat meningkatkan minat beli.

Hasil olahan diatas selanjutnya menunjukkan bahwa, sikap konsumen terhadap 
merek di advergames tidak memoderasi pengaruh penempatan produk dan kesesuaian iklan terhadap minat beli pada produk Adidas. Hal ini ditunjukkan dengan nilai signifikan sebesar 0,894 untuk penempatan produk dengan sikap konsumen terhadap merek di advergames dan 0,362 untuk kesesuaian iklan dengan sikap konsumen terhadap merek di advergames lebih besar dari tingkat signifikan 0,05 . Artinya pada produk Adidas yang dianggap sesuai dengan konteks game, sikap konsumen terhadap merek di advergames tidak dapat memperkuat atau memperlemah pengaruh yang dihasilkan dari penempatan produk dan kesesuaian iklan terhadap minat beli. Sehingga dapat disimpulkan bahwa ketika sikap konsumen terhadap merek di advergames positif atau negatif tetap saja tidak berdampak pada pengaruh penempatan produk dan kesesuaian iklan terhadap minat beli.

\begin{tabular}{|c|c|c|c|c|c|}
\hline \multirow{3}{*}{ Model } & \multicolumn{3}{|c|}{ Coefficients } & \multirow{3}{*}{$\mathbf{t}$} & \multirow{3}{*}{ Sig } \\
\hline & \multicolumn{2}{|c|}{$\begin{array}{l}\text { Unstandardized } \\
\text { Coefficients }\end{array}$} & \multirow{2}{*}{$\begin{array}{c}\text { Standardized } \\
\text { Coefficients }\end{array}$} & & \\
\hline & B & Std. Error & & & \\
\hline (constant) & 6.939 & 1.733 & & 4.003 & .000 \\
\hline Penempatan Produk Nissan & .004 & .081 & .005 & .046 & .963 \\
\hline Kesesuaian Iklan Nissan & .059 & .095 & .086 & .620 & .537 \\
\hline $\begin{array}{l}\text { Sikap Konsumen terhadap } \\
\text { Merek Nissan (SK) }\end{array}$ & .214 & .074 & .352 & 2.904 & .005 \\
\hline PPAS_X_SK Nissan & .021 & .024 & .140 & .872 & .385 \\
\hline KSAS_X_SK Nissan & -.014 & .022 & -.114 & -.658 & .512 \\
\hline \multicolumn{6}{|c|}{ a. Dependent Variable: MBNS (Minat Beli Nissan) } \\
\hline
\end{tabular}

Berdasarkan pengolahan data diatas, menunjukkan bahwa penempatan produk dan kesesuaian iklan tidak mempengaruhi minat beli konsumen pada produk yang tidak sesuai dengan konteks games, dimana jenis produk yang digunakan adalah Nissan. Hal ini ditunjukkan dengan nilai signifikan sebesar 0,963 untuk penempatan produk dan nilai signifikan sebesar 0,537 untuk kesesuaian iklan lebih besar dari nilai signifikan 0,05. Pada penelitian ini, rata-rata skor tertinggi terdapat pada aspek penempatan produk di butir 5 sebesar 2,97 yang menyatakan bahwa responden mengetahui bahwa nama merek Nissan muncul pada adboard di sekitar lapangan ketika karakter pemain game PES 2016 bermain di sekitar lapangan. Hal ini sesuai dengan penelitian yang dilakukan oleh Zulganef dan Ramadhika (2014) yang mengungkapkan bahwa konsumen tahu produk Cross muncul pada acara X-Factor, salah satunya pada gelas yang diletakkan di meja Juri, namun product placement tidak berpengaruh terhadap minat beli produk Cross pada acara X-Faxtor tersebut. Hal tersebut dikarenakan product placement untuk produk yang kurang dikenal tidak memberikan efek terhadap minat beli. Sedangkan untuk aspek kesesuaian iklan tidak berpengaruh terhadap minat beli dikarenakan tidak adanya kesesuaian iklan merek atau produk dengan konteks game. Hal tersebut dapat dibuktikkan pada butir 3 dengan rata-rata skor terendah sebesar 1,93 pada aspek kesesuaian iklan, dimana menunjukkan bahwa rata-rata responden tidak setuju dengan pernyataan yang menyatakan merek Nissan merupakan jenis produk olahraga yang sesuai diiklankan pada konteks game olahraga seperti game PES 2016. Artinya, ketidaksesuaian iklan merek atau produk yang muncul pada game, membuat tanggapan negatif konsumen terhadap merek sehingga tidak mempengaruhi minat beli.

Berdasarkan pengolahan diatas juga menunjukkan adanya pengaruh yang dihasilkan dari variabel sikap terhadap merek 
di advergames terhadap minat beli konsumen pada produk Nissan. Hal tersebut ditunjukkan dengan nilai signifikan sebesar 0,005 lebih kecil dari nilai signifikan 0,05 . Hal ini dapat terjadi dikarenakan konsumen memiliki persepsi dan pandangan lain yang mendukung sikap terhadap merek dalam minat beli konsumen terhadap suatu produk.

Hasil olahan data diatas selanjutnya menunjukkan bahwa, sikap konsumen terhadap merek di advergames tidak dapat memoderasi pengaruh dari penempatan produk dan kesesuaian iklan terhadap minat beli pada produk Nissan. Hal ini ditunjukkan dengan nilai signifikan sebesar 0,385 untuk penempatan produk dengan sikap konsumen terhadap merek di advergames dan nilai signifikan sebesar 0,512 untuk kesesuaian iklan dengan sikap konsumen terhadap merek di advergames lebih besar dari nilai signifikan 0,05 . Artinya, sekalipun sikap konsumen terhadap merek di advergames menunjukkan respon positif atau negatif tetap saja tidak dapat memperkuat atau memperlemah pengaruh dari penempatan produk dan kesesuaian iklan terhadap minat beli konsumen pada produk Nissan yang dianggap sebagai merek atau produk yang tidak sesuai dengan konteks game PES 2016.

\section{KESIMPULAN DAN SARAN}

\section{Kesimpulan}

Dari hasil analisis dan pembahasan bab sebelumnya, diperoleh kesimpulan sebagai berikut :

1. Penempatan produk, kesesuaian iklan dan sikap konsumen terhadap merek di advergames berpengaruh secara signifikan terhadap minat beli pada produk Adidas.

2. Sebagai produk yang dianggap sesuai dengan konteks game PES 2016 pada mobile games.

3. Sikap konsumen terhadap merek di advergames tidak memoderasi pengaruh penempatan produk dan kesesuaian iklan terhadap minat beli pada produk Adidas.

4. Penempatan produk dan kesesuaian iklan tidak berpengaruh secara signifikan terhadap minat beli pada produk Nissan, sedangkan sikap konsumen terhadap merek di advergames berpengaruh pada minat beli pada produk Nissan, sebagai produk yang dianggap tidak sesuai dengan konteks game PES 2016 pada mobile games.

5. Sikap konsumen terhadap merek di advergames juga tidak memoderasi pengaruh penempatan produk dan kesesuaian iklan terhadap minat beli pada produk Nissan.

\section{Keterbatasan Penelitian}

Berdasarkan hasil analisis dan pembahasan, maka keterbatasan dalam penelitian ini adalah sebagai berikut :

1. Pada penelitian ini jumlah responden yang diteliti sebanyak 100 responden saja, berdasarkan hasil penelitian ini peneliti menduga jumlah tersebut belum mencakup keseluruhan responden yang layak untuk berpartisipasi, sehingga belum mampu menunjukkan hasil pengaruh yang diharapkan.

2. Obyek pada penelitian ini hanya menggunakan mahasiswa dan mahasiswi, peneliti menduga obyek tersebut belum mampu menggambarkan secara keseluruhan mengenai sikap konsumen terhadap merek di advergames, sehingga penelitian ini kurang mendalam membahas pengaruh yang dihasilkan.

3. Produk yang digunakan pada penelitian ini menggunakan produk yang tidak setara dari sisi harga produk, yaitu untuk produk yang dianggap sesuai dengan konteks game, peneliti menggunakan produk Adidas dan untuk produk yang dianggap tidak sesuai dengan konteks game, peneliti menggunakan produk Nissan. Dimana produk Adidas dirasa lebih terjangkau dibandingkan produk Nissan bagi kalangan responden dalam penelitian ini, sehingga mengakibatkan kecenderungan jawaban responden untuk minat beli lebih pada produk Adidas. Sehingga hal tersebut menjadi keterbatasan dalam pemilihan merek atau produk.

4. Hasil penelitian ini belum mampu menggambarkan bagaimana minat beli untuk kelompok konsumen perempuan. Dikarenakan dalam penelitian ini 
menggunakan game PES 2016 yang merupakan game olahraga sepakbola yang cenderung digunakan kelompok laki-laki sehingga sedikit jumlah kelompok perempuan yang berpartisipasi dalam penelitian ini.

\section{Saran Penelitian Mendatang}

Berdasarkan hasil analisis dan pembahasan, maka saran untuk penelitian mendatang adalah sebagai berikut :

1. Penelitian selanjutnya diharapkan dapat menentukan jumlah responden yang lebih besar, dan dapat menggunakan obyek selain mahasiswa, agar pada penelitian selanjutnya dapat lebih mengkaji lagi mengenai pengaruh yang dihasilkan dari jumlah responden yang lebih besar dan obyek penelitian yang bervariasi.

2. Menambah variabel lain, selain variabel sikap konsumen terhadap merek di advergames untuk memoderasi pengaruh penempatan produk dan kesesuaian iklan terhadap minat beli, dikarenakan pada penelitian ini sikap konsumen terhadap merek di advergames pada produk yang sesuai dan tidak sesuai belum mampu menunjukkan pengaruh yang memperkuat atau memperlemah aspek penempatan produk dan kesesuaian iklan terhadap minat beli.

3. Penelitian selanjutnya diharapkan dapat menggunakan produk dalam kategoriyang sama atau setara, sehingga dimungkinkan dapat mengarahkan jawaban responden menurut persepsi dan pemikiran mereka dan memberikan penilaian terhadap penempatan produk dan kesesuaian iklan dan sikap terhadap merek di advergames terhadap minat beli.

4. Pada penelitian selanjutnya diharapkan lebih spesifik dalam menentukan game yang akan di uji, yang dapat digunakan kedua kelompok sampel laki-laki dan perempuan, dan dapat menentukan jumlah sampel yang sebanding untuk masing-masing kelompok, sehingga dimungkinkan pada penelitian selanjutnya dapat lebih menjelaskan bagaimana minat beli dari kedua kelompok.

5. Penelitianselanjutnyadapatmenggunakan pendekatan kualitatif, agar dapat lebih mendalam dalam menjelaskan pengaruh yang dihasilkan dari setiap variabel yang digunakan.

\section{DAFTAR PUSTAKA}

Ajisaksono, Yohannes Vici., dan Bambang Wiratmojo. 2014. Efektivitas Product Placement dalam Game Online. Fakultas Ilmu Sosial dan Ilmu Politik. Universitas Atma Jaya Yogyakarta. http://e-journal.uajy.ac.id. 16 November 2015.

Chaney, Isabella M., Ku-Ho Lin, dan James Chaney. 2004. The Effect of Billboards Within The Gaming Environment. Journal of Interactive Advertising. University of London. http://web.nchu. edu. 3 Desember 2015.

Chen, Huan dan Eric Haley. 2014. Product Placement in Social Games : Consumer Experiences in China. Journal of Advertising, 43(3), 286-295. Penn State Erie, The Behrend College, Erie, Pennsylvania, USA. University of Tennessee, Knoxville, Tennessee, USA.

http://www.arbamedia.com/2015/04/ pertumbuhan-dan-perkembangangame-mobile.html diakses pada tanggal 30 Juni 2015

http://www.kampus.marketing.co.id/ segmentasi-pasar/ diakses pada tanggal 20 Juni 2015

Kotler, Philip, dan Gary Armstrong. 2008a. Prinsip-Prinsip Pemasaran. Diterjemahkan oleh : Bob Sabran. 2008. Edisi 12. Jilid 1. Jakarta: Erlangga.

Kuhn Kerri., Anita Love, dan Nigel K.L1. Pope. 2004. Brand Placements In Computer and Video Games an Overview and Research Questions. Grifth University. http://www98.griffith.edu.au. 3 Desember 2015.

Kurniawan, Iqbal. Mei 2015. Pengguna Smartphone Di Asia Bermain Game Mobile Lebih Lama Dibandingkan 
Benua Lain. http://id.techinasia.com. 30 Juni 2015

Lee, Mira dan Ronald J. Faber. 2007. Effect of Product Placement in Online Games on Brand Memory: A Perspective of Limited-Capacity Model of Attention. Journal of Advertising, 36 (75-90).

Moore, Robert. S., Claire Allison Stammerjohan., dan Robin A. 2005. Coulter. Banner Advertiser-Web Site Context Congruity and Color Effects on Attention and Attitudes. Journal of Advertising, Vol. 34, no. 2 (summer 2005), pp. 71-84.

Nelson, Heejo Keum, dan Ronald A. Yaros. (2004). Advertainmennt or Adcreep ? Game Players' Attitude Toward Advertising and Product Placements in Computer Games. Journal of Interactive Advertising 5 (1).

Nugroho, Eko. Maret 2013. Jangan Terlena Bikin Game "Biasa Saja". http://tekno. kompas.com. 30 Juni 2015

Panda, T. K . ( 2004 ). Effectiveness Of Product Placements In Indian Films and Its Effects On Brand Memory and Attitude with Special Reference to Hindi Films. The ICFAI Journal Of Marketing Management.

Parreno-Marti, Jose, Joaquin Aldas-Manzano, Rafael Curras-Perez, dan Isabel SanchezGarcia. 2013. Factors Contributing Brand Attitude in Advergames : Entertainment and Irritation. Journal of Brand Management (2013) 20, 374 388 .

Peters, Sara., dan Glenn Leshner. 2013. Get in the Game : The Effects of Game Product Congruity and Product Placement Proximity on Game Players Processing of Brands Embedded in Advergames. Journal of Advertising, 42 (2-3), 113130. University of Missouri, Columbia, Missouri, USA.

Pramoedya, Ode. 2013. Pengaruh Product
Placement (Penempatan Produk) Samsung Galaxy S III Pada Drama Korea Big (2012) Terhadap Minat Beli Konsumen. Program Studi Ilmu Administrasi Niaga. Fakultas Ilmu Sosial dan Ilmu Politik. Universitas Indonesia. http://lib.ui.ac.id. 23 Februari 2016.

Pujadi, Bambang. 2010. Studi Tentang Pengaruh Citra Merek Terhadap Minat Beli Melalui Sikap Terhadap Merek (Kasus Pada Merek Pasta Gigi Ciptadent di Semarang). Program Studi Magister Manajemen. Program Pasca Sarjana. Universitas Diponegoro Semarang. http://eprints.undip.ac.id. 8 Maret 2016.

Qolbi, Ummas Sahibul., Achmad Fauzi., dan Sunarti. 2014. Pengaruh Iklan Terhadap Sikap Konsumen. Fakults Ilmu Administrasi. Universitas Brawijaya. Malang. http://download.portalgaruda. org/. 15 Juni 2015.

Sahni Damerianta. 2009. Pengaruh Penerapan Periklanan di Internet dan Pemasaran melalui E-mail terhadap pemrosesan Informasi dan Keputusan Pembelian oleh Konsumen. Semimar Nasional Aplikasi Teknologi Informasi. STMK Jakarta. Fakultas Ekonomi Jurusan Manajemen Universitas Gunadarma. http://repository.gunadarma.ac.id/. 15 Juni 2015.

Schiffman, Leon G., dan Kanuk, Lezlie Lazar. 2008. Perilaku Konsumen. Edisi ke 7. Jakarta : PT. Indeks. Terjemahan.

Sukandar, Eryadi. 2012. Pengaruh Kongruitas Iklan Online dan Website Terhadap Sikap Konsumen Atas Website (Studi Pada Website Detik.com). Fakultas Ilmu Sosial dan Ilmu Politik. Program Studi Ilmu Administrasi Niaga. Universitas Indonesia. http://lib.ui.ac.id/. 23 Februari 2016.

Suwito, Arfian. 2007. Pengaruh Sikap Terhadap Merek dan Sikap Terhadap 
Iklan Pada Minat Beli Konsumen. Wise, Kevin., Paul D. Bolls., Hyo Kim., Arun Fakultas Ekonomi Jurusan Manajemen. Venkataraman, dan Ryan Meyer. 2008. Universitas Muhammadiyah Surakarta. Enjoyment of Advergames And Brand http://eprints.ums.ac.id. 12 Maret 2016. Attitudes : The Impact Of Thematic

Winkler, Tina dan Kathy Buckner. 2006. Receptiveness of Gamers to Embedded Brand Messages in Advergames : Attitudes Towards Product Placement. Napier University, Edinburgh, UK.

Williams, Kaylene., Alfred Petrosky., Edward Hernandez, dan Robert Page, Jr. 2011. Product Placement Effectiveness : Revisited and Renewed. Journal of Management and Marketing Reseacrh. Pp. 1-24. http://www.aabri.com. 15 Juni 2015.

Wire, P.R. Mei 2015. Appier Rilis Survey Perilaku Pengguna Gadget terhadap Iklan yang Muncul di Game. http:// www.antaranews.com/berita/498627. 30 Juni 2015 Relevance. Journal Of Interactive Advertising,9,14-29.

Xiong, Shili., Brittany R.L Duff, dan Jiachen Yao. 2015. I Think I just Saw Another Version Of It : An Investigation of Congruity Effects Between Product Placement and Webpage AD As Well As EcposureTiming On Product Recognition. University of Illinois, Urbana, IL.

Zulganaef., dan Alda Ramadhika. 2014. Analisis Efek Product Placement Dan Brand Awaraness Terhadap Niat Beli. Dipublikasian oleh Fakultas Ekonomika dan Bisnis Universitas Kristen Satya Wacana. Salatiga. http://repository. uksw.edu/bitstream. 23 Februari 2016 